ISBN: 2338-8021; E-ISSN: 2338-8269

\title{
ANALISIS EFEKTIVITAS PROGRAM PEMBERDAYAAN ANAK JALANAN DI RUMAH SINGGAH TABAYUN KECAMATAN CIBINONG, KABUPATEN BOGOR
}

\author{
(Analysis of Street Children Empowerment Program \\ in Tabayun Shelter Cibinong Sub District, Bogor Distric)
}

\author{
Dian Permata Sari ${ }^{1)}$ dan Titik Sumarti ${ }^{1)}$ \\ 1) Departemen Sains Komunikasi dan Pengembangan Masyarakat, Fakultas Ekologi Manusia, Institut \\ Pertanian Bogor, Darmaga Bogor 16680, Indonesia \\ Email: dianps16@gmail.com dan titik_sumarti@apps.ipb.ac.id
}

\begin{abstract}
This study aimed to analyze the relationship between the characteristics of the participants to effectiveness rate of street children empowerment and to analyze the correlation between the effectiveness of behavior change program with street children. This research was conducted in Cibinong, Bogor using a quantitative approach through survey method of 30 respondents from participants in Tabayun Shelter program. This research also supported by qualitative data with in-depth interviews, field observation, and document tracking. Quantitative data analysis was performed using Rank Spearman and Chi-Square correlation test. The results of this study indicate that the program participant characteristics such as age, type of job, working hours have relation with the level of program effectiveness. Test results showed that there are correlations between the levels of program effectiveness with program participants' behavior changes in the level of knowledge. This research also shows that program effectiveness in Shelter Tabayun still low.
\end{abstract}

Keywords: effectiveness, characteristics, behavior changes

\begin{abstract}
ABSTRAK
Penelitian ini bertujuan untuk menganalisis hubungan antara karakteristik peserta dengan tingkat efektivitas program pemberdayaan anak jalanan dan menganalisis hubungan tingkat efektivitas program dengan perubahan perilaku anak jalanan. Penelitian ini dilakukan di Cibinong, Kabupaten Bogor dengan menggunakan pendekatan kuantitatif melalui metode survei terhadap 30 responden peserta program di Rumah Singgah Tabayun. Penelitian ini juga didukung dengan data kualitatif dengan metode wawancara mendalam, observasi lapang, dan penelusuran dokumen. Analisis data kuantitatif dilakukan menggunakan uji korelasi Rank Spearman dan ChiSquare. Hasil dari penelitian ini menunjukkan bahwa karakteristik peserta program seperti usia, jenis pekerjaan, dan jam kerja memiliki hubungan dengan tingkat efektivitas program. Hasil uji korelasi menunjukkan bahwa terdapat hubungan antara tingkat efektivitas program dengan perubahan perilaku peserta program di tingkat perubahan pengetahuan. Penelitian ini juga menunjukkan bahwa tingkat efektivitas program di Rumah Singgah Tabayun masih rendah.
\end{abstract}

Kata Kunci: efektivitas, karakteristik, perubahan perilaku

\section{PENDAHULUAN}

Data yang dikeluarkan oleh Badan Pusat Statistik (BPS) menyebutkan bahwa anak jalanan di Indonesia berjumlah 154.861 jiwa pada tahun 2008. Berdasarkan data Kementerian Sosial Republik Indonesia tahun 2016, jumlah anak jalanan di Indonesia meningkat mencapai 4,1 juta jiwa.
Penanganan masalah anak merupakan tanggungjawab bersama antara masyarakat dan pemerintah, baik pemerintah pusat, provinsi, kabupaten/kota, sebagaimana yang di amanatkan dalam Undang-Undang Nomor 35 Tahun 2014 hasil dari revisi Undang-Undang Nomor 23 Tahun 2002 tentang perlindungan anak, diantaranya dalam pasal $22,24,25$, dan 26, yaitu; negara dan pemerintah berkewajiban 
dan bertanggungjawab memberikan dukungan sarana dan prasarana dalam penyelenggaraan perlindungan anak; negara dan Pemerintah menjamin anak untuk mempergunakan haknya dalam menyampaikan pendapat sesuai dengan usia dan tingkat kecerdasan anak; kewajiban dan tanggungjawab masyarakat terhadap perlindungan anak dilaksanakan melalui kegiatan peran masyarakat dalam penyelenggaraan perlindungan anak. Maka dari itu perlulah program pemberdayaan baik dari pemerintah, LSM, masyarakat, maupun akademisi.

Pemberdayaan anak jalanan ini sangat penting dilakukan. Salah satu program pemberdayaan anak jalanan adalah berdirinya Rumah Singgah Tabayun di Cibinong, Kabupaten Bogor. Rumah Singgah ini didirikan pada tahun 2008. Berdasarkan keterangan salah satu pengurus Rumah Singgah Tabayun, anak-anak tersebut berasal dari kabupaten ataupun pedesaan yang sengaja untuk mencari penghidupan di kota. Program tersebut telah berjalan kurang lebih lima tahun, namun hingga saat ini masih banyak anak jalanan yang kembali turun ke jalan. Rumah Singgah Tabayun memiliki tujuan salah satunya adalah pemenuhan hak anak. Hak anak dalam Undang-Undang tentang Hak Asasi Manusia diatur dalam ketentuan Pasal 52 sampai dengan Pasal 66 yang diantaranya, yakni hak atas persamaan, hak untuk memiliki nama, hak untuk memiliki kewarganegaraan, hak atas perlindungan, hak atas makanan, hak atas pendidikan, hak atas kesehatan, hak rekreasi, hak bermain, hak atas peran dan keterlibatan dalam pembangunan.

Oleh sebab itu, akan sangat menarik apabila kita mengkaji sejauh mana program-program tersebut mampu memberdayakan anak jalanan. Untuk mengatasi masalah anak jalanan, perlu adanya dukungan dari berbagai pihak agar bekerjasama dalam mengentaskan masalah anak jalanan secara partisipatif. Sehingga penting bagi kita untuk mengetahui tingkat efektivitas program pemberdayaan bagi anak jalanan.

Seorang anak seharusnya dibawah perlindungan orangtua maupun pemerintah sehingga dapat hidup layak dan menempuh pendidikan selayaknya anak pada usianya. Pada tahun
2016, terdapat 150 anak jalanan yang mengikuti program pemberdayaan di Rumah Singgah Tabayun Kecamatan Cibinong, Kabupaten Bogor. Oleh karena itu, bagaimana karakteristik dan apa latar belakang menjadi anak jalanan?

Adanya program-program pemberdayaan tersebut, tidak menutup kemungkinan bahwa anak jalanan masih terus bertambah. Perlu peningkatan efektivitas program agar yang diinginkan sesuai dengan harapan. Semakin banyak anak jalanan, maka program-program untuk mengatasi masalah anak jalanan juga semakin meningkat. Efektivitas program pemberdayaan anak jalanan harus dilihat dari sisi anak jalanan tersebut karena mereka merupakan pihak yang menjadi sasaran dan mendapatkan efek dari program. Ketika program tersebut sudah ada untuk mengatasi masalah anak jalanan, kita perlu mengetahui bagaimana tingkat efektivitas program Rumah Singgah Tabayun dalam pemberdayaan anak jalanan?

Efektivitas suatu program dapat dipengaruhi oleh beberapa faktor dari sisi anak jalanan ataupun sisi pengelola program itu sendiri. Faktor tersebut salah satunya dapat dilihat dari karakteristik sasaran program atau anak jalanan. Anak jalanan tentunya memiliki karakteristik masing-masing sehingga program tersebut dapat berjalan dengan baik ataupun tidak. Sehingga perlu diketahui bagaimana hubungan antara karakteristik anak jalanan dengan tingkat efektivitas program pemberdayaan anak jalanan di Rumah Singgah Tabayun?

Setelah melihat efektivitas suatu program, maka kita perlu mengetahui perubahan perilaku yang dialami oleh anak jalanan untuk mengetahui dampak dari pelaksanaan program, maka perlu diketahui bagaimana hubungan antara tingkat efektivitas program pemberdayaan anak jalanan dengan perubahan perilaku anak jalanan?

\section{PENDEKATAN TEORITIS}

\section{Anak Jalanan}

Anak adalah seseorang yang belum berusia 18 tahun, termasuk anak yang masih dalam 
kandungan (UU No. 35 Tahun 2014). Permasalahan anak jalanan di Indonesia sudah bukan menjadi hal yang baru lagi. Sejak dulu masalah tersebut kian marak dan belum dapat di selesaikan hingga saat ini. Direktorat Kesejahteraan Anak, Keluarga dan Lanjut Usia, Departemen Sosial (2001) memaparkan bahwa anak jalanan adalah anak yang sebagian besar waktunya dihabiskan untuk mencari nafkah atau berkeliaran di jalanan atau tempat - tempat umum lainnya, usia mereka berkisar dari 6 tahun sampai 18 tahun. Adapun waktu yang dihabiskan di jalan lebih dari 4 jam dalam satu hari. Pada dasarnya anak jalanan menghabiskan waktunya di jalan demi mencari nafkah, baik dengan kerelaan hati maupun dengan paksaan orang tuanya.

\section{Efektivitas Program}

Kata efektif berasal dari bahasa inggris effective artinya berhasil. Sesuatu yang dilakukan dengan baik. Robbins (1994) mendefinisikan efektivitas sebagai tingkat pencapaian organisasi jangka pendek dan jangka panjang. Efektivitas memiliki arti berhasil atau tepat guna. Efektif merupakan kata dasar, sementara kata sifat dari efektif adalah efektivitas. Budiani (2007) menyatakan bahwa untuk mengukur efektivitas suatu program dapat dilakukan dengan menggunakan variabel-variabel sebagai berikut :

1. Ketepatan sasaran program, yaitu sejauhmana peserta program tepat dengan sasaran yang sudah ditentukan sebelumnya.

2. Sosialisasi program, yaitu kemampuan penyelenggara program dalam melakukan sosialisasi program sehingga informasi mengenai pelaksanaan program dapat tersampaikan kepada masyarakat pada umumnya dan sasaran peserta program pada khususnya.

3. Pencapaian Tujuan program, yaitu sejauhmana kesesuaian antara hasil pelaksanaan program dengan tujuan program yang telah ditetapkan sebelumnya.

4. Pemantuan program, yaitu kegiatan yang dilakukan setelah dilaksanakannya program sebagai bentuk perhatian kepada peserta program.

\section{Karakteristik Anak Jalanan}

1. Jenis Kelamin

Sebagai makhluk Tuhan Yang Maha Esa, manusia dibedakan menurut jenis kelaminnya yaitu pria dan wanita. Menurut Hungu (2007) jenis kelamin (seks) adalah perbedaan antara perempuan dengan lakilaki secara biologis sejak seseorang lahir. Seks berkaitan dengan tubuh laki-laki dan perempuan, dimana laki-laki memproduksikan sperma, sementara perempuan menghasilkan sel telur dan secara biologis mampu untuk menstruasi, hamil dan menyusui. Perbedaan biologis dan fungsi biologis laki-laki dan perempuan tidak dapat dipertukarkan diantara keduanya, dan fungsinya tetap dengan lakilaki dan perempuan pada segala ras yang ada di muka bumi.

2. Usia

Direktorat Kesejahteran Anak, Keluarga dan Lanjut Usia, Departemen Sosial (2001) memaparkan bahwa anak jalanan adalah anak yang sebagian besar waktunya dihabiskan untuk mencari nafkah atau berkeliaran di jalanan atau tempattempat umum lainnya, usia mereka berkisar dari 5 tahun sampain 18 tahun. Selain itu dijelaskan oleh Departemen Sosial RI (2001), indikator anak jalanan menurut usianya adalah anak yang berusia berkisar antara 5 sampai 18 tahun.

3. Pendidikan

Pendidikan adalah usaha sadar dan terencana untuk mewujudkan suasana belajar dan proses pembelajaran agar peserta didik secara aktif mengembangkan potensi dirinya untuk memiliki kekuatan spiritual keagamaan, pengendalian diri, kepribadian, kecerdasan, akhlak mulia, serta keterampilan yang diperlukan dirinya, masyarakat, bangsa dan Negara (UU RI No. 20 Tahun 2003 Pasal 1). Menurut Badan Pusat Statistik, pendidikan terdiri atas pendidikan formal dan pendidikan nonformal. Pendidikan formal adalah jalur pendidikan yang terstruktur dan berjenjang yang terdiri atas pendidikan dasar, pendidikan menengah, dan pendidikan tinggi, meliputi SD/MI/Sederajat, 
SMP/MTs/Sederajat, SMA/MA/Sederajat dan PT.

4. Jenis Pekerjaan

Menurut Departemen Sosial RI (2001), indikator anak jalanan menurut aktivitas yang dilakukan oleh anak jalanan adalah antara lain memiliki aktivitas: menyemir sepatu, mengasong, menjadi calo, menjajakan koran atau majalah, mengelap mobil, mencuci kendaraan, menjadi pemulung, pengamen, menjadi kuli angkut, menyewakan payung, menjadi penghubung atau penjual jasa. Menurut Departemen Sosial RI (2002), aktivitas yang dilakukan anak jalanan di jalanan diantaranya adalah bekerja baik itu mengamen, mengemis, memulung, menjual koran, mengasong, mencuci bus, menyemir sepatu, menjadi calo, dan menggelandang.

\section{Tingkat Pendapatan}

Menurut BPS, tingkat pendapatan adalah jumlah penerimaan berupa uang atau barang yang dihasilkan oleh segenap orang yang merupakan balas jasa untuk faktorfaktor produksi. Ada tiga sumber penerimaan, di antaranya pendapatan dari gaji dan upah yaitu balas jasa terhadap kesediaan orang menjadi tenaga kerja, pendapatan dari asset produktif yaitu asset yang memberikan pemasukan atas balas jasa penggunaanya, dan pendapatan dari pemerintah atau penerimaan transfer adalah pendapatan yang di terima bukan sebagai balas jasa atau input yang di berikan.

\section{Perubahan Perilaku}

Pada dasarnya program pemberdayaan yang dilakukan terhadap anak jalanan diarahkan pada perubahan perilaku secara psikologis, yang menurut Bloom dalam Mugniesyah (2006) mencakup tiga ranah, yaitu:

(1) Ranah Kognitif, perubahan yang diharapkan adalah dari tidak mengetahui menjadi mengetahui, dari tidak paham menjadi paham, dari tidak mengerti menjadi mengerti tentang sesuatu yang dipelajari individu yang belajar.

(2) Ranah Afektif, perubahan yang diharapkan adalah perubahan dari sikap negatif menjadi sikap positif, dari sikap yang salah menjadi sikap yang baik, dari sikap menolak menjadi sikap menerima terhadap sesuatu yang dipelajari oleh individu yang belajar.

(3) Ranah Psikomotorik, perubahan yang diharapkan adalah dari tidak melaksanakan menjadi melaksanakan, dari tidak adopsi menjadi adopsi, dari tidak terampil menjadi terampil, dari tidak melakukan, berbuat, membentuk, dan sebagainya berubah menjadi dapat melakukan, dapat membuat, dan dapat membentuk.

\section{Kerangka Pemikiran}

Kerangka pemikiran ini menjelaskan korelasi antar variabel penelitian. Efektivitas program penting untuk melihat keberhasilan suatu program karena selama ini sudah banyak program berjalan namun anak jalanan tetap bertambah, setelah program selesai peserta binaan kembali menjadi anak jalanan.

Dalam melihat tingkat efektivitas program digunakan indikator ketepatan sasaran program, dimana suatu program yang telah dijalankan sudah sesuai dengan sasaran atau tidak. Kemudian terdapat keberhasilan sosialisasi program, pencapaian tujuan, dan pemantauan program. Efektif atau tidaknya program ditentukan oleh karakteristik dan latar belakang anak jalanan. Anak jalanan yang berada di Rumah Singgah Tabayun memiliki karakteristik yang khas pada setiap individunya. Program yang sesuai dengan kebutuhan anak jalanan adalah yang efektif. Keberhasilan/efektivitas program akan menentukan perubahan perilaku dari anak jalanan. Variabel dari perubahan perilaku tersebut adalah perubahan pada tingkat pengetahuan, tingkat sikap, dan tingkat keterampilan.

\section{Hipotesis}

1. Diduga jenis kelamin anak jalanan memiliki hubungan dengan tingkat efektivitas program pemberdayaan anak jalanan di Rumah Singgah Tabayun.

2. Diduga usia anak jalanan memiliki hubungan dengan tingkat efektivitas program pemberdayaan anak jalanan di Rumah Singgah Tabayun.

3. Diduga tingkat pendidikan anak jalanan memiliki hubungan dengan tingkat 
efektivitas program pemberdayaan anak jalanan di Rumah Singgah Tabayun.

4. Diduga derajat penghargaan pekerjaan anak jalanan memiliki hubungan dengan tingkat efektivitas program pemberdayaan anak jalanan di Rumah Singgah Tabayun.

5. Diduga jam kerja anak jalanan memiliki hubungan dengan tingkat efektivitas program pemberdayaan anak jalanan di Rumah Singgah Tabayun.

6. Diduga tingkat pendapatan anak jalanan memiliki hubungan dengan tingkat efektivitas program pemberdayaan anak jalanan di Rumah Singgah Tabayun.

7. Diduga tingkat efektivitas program pemberdayaan anak jalanan memiliki hubungan dengan perubahan tingkat pengetahuan anak jalanan.

8. Diduga tingkat efektivitas program pemberdayaan anak jalanan memiliki hubungan dengan perubahan sikap anak jalanan.

9. Diduga tingkat efektivitas program pemberdayaan anak jalanan memiliki hubungan dengan perubahan keterampilan/ tindakan anak jalanan.

\begin{tabular}{|c|c|c|}
\hline $\begin{array}{ll}\text { Karakteristik Anak } \\
\text { Jalanan: } \\
\text { 1. Jenis Kelamin } \\
\text { 2. Usia } \\
\text { 3. } & \text { Tingkat } \\
& \text { Pendidikan } \\
\text { 4. } & \text { Derajat } \\
& \text { Penghargaan } \\
& \text { Pekerjaan } \\
\text { 5. Jam Kerja } \\
\text { 6. } & \text { Tingkat } \\
& \text { Pendapatan }\end{array}$ & $\begin{array}{l}\text { Tingkat Efektivitas } \\
\text { Program: } \\
\text { 1. Sasaran program } \\
\text { 2. Sosialisasi } \\
\text { program } \\
\text { 3. Tujuan program } \\
\text { 4. Pemantauan } \\
\text { program }\end{array}$ & $\begin{array}{l}\text { Perubahan } \\
\text { Perilaku: } \\
\text { 1. Tingkat } \\
\text { Pengetahuan } \\
\text { 2. Tingkat } \\
\text { Sikap } \\
\text { 3. Tingkat } \\
\text { Keterampilan }\end{array}$ \\
\hline
\end{tabular}

Keterangan :

Hubungan :

Gambar 1. Kerangka pemikiran

\section{METODE PENELITIAN}

Pendekatan penelitian yang digunakan untuk menggali fakta, data, dan informasi dalam penelitian tentang efektivitas program pemberdayaan anak jalanan ini adalah pendekatan kuantitatif yang didukung dengan data kualitatif. Pendekatan kuantitatif merupakan pendekatan penelitian yang dilakukan dengan melihat hubungan antar variabel. Penelitian kuantitatif dilakukan dengan metode survei melalui instrumen kuesioner yang diberikan kepada responden dengan dampingan peneliti. Pendekatan kuantitatif berorientasi pada data sampel di lapangan. Sampel diambil untuk mewakili keseluruhan populasi (Singarimbun dan Efendi 2008). Selain pendekatan kuantitatif, penelitian ini didukung pula oleh data kualitatif. Data kualitatif digunakan untuk mendukung dan menginterpretasi terhadap data yang di dapatkan dari pendekatan kuantitatif mengenai hubungan antara karakteristik peserta program dengan tingkat efektivitas program pemberdayaan tersebut serta hubungannya dengan perubahan perilaku anak jalanan.

Lokasi penelitian bertempat di Kecamatan Cibinong, Kabupaten Bogor, Jawa Barat. Lokasi tersebut dipilih secara purposive (sengaja) karena Cibinong merupakan pusat Kabupaten Bogor yang memiliki jarak dekat dengan ibukota Jakarta sehingga terdapat bermacam anak jalanan. Rumah Singgah Tabayun merupakan salah satu bentuk program pemberdayaan anak jalanan yang berdiri lebih dari lima tahun. Anak jalanan di Rumah Singgah Tabayun memiliki permasalahan yang beragam. Kegiatan penelitian ini dilaksanakan dalam waktu enam bulan, terhitung mulai Agustus 2016 hingga Februari 2017.

Data yang digunakan dalam penelitian ini adalah data primer dan data sekunder. Data primer didapatkan langsung di lapang dengan cara survei menggunakan kuesioner, observasi dan wawancara mendalam menggunakan panduan wawancara. Sementara itu, data sekunder diperoleh melalui studi literatur dan informasi tertulis yang dapat digunakan dan sesuai dengan topik penelitian. Data yang diperoleh berupa data kuantitatif dan data kualitatif. Data kuantitatif diolah dengan uji hubungan untuk melihat hubungan antara variabel dengan menggunakan Rank Spearman dan Chi Square. Pengelolaan data dilakukan dengan menggunakan SPSS 15.0 for Windows dan Microsoft Excell 2010. Sementara itu, untuk data kualitatif digunakan untuk mendukung data kuantitatif dengan menganalisis melalui reduksi data, deskripsi, 
menyajikan data, dan menarik kesimpulan untuk memperkuat hasil penelitian. Korelasi rank Speraman digunakan untuk mengetahui ada tidaknya hubungan antara variabel bebas dan variabel terikat yang berasal dari data skala ordinal. Tanda bintang (*) yang terdapat pada nilai korelasi koefisien juga menunjukan signifikansi atau hubungan antara variabel. Semakin banyak jumlah bintang (*) pada koefisien korelasi, semakin tinggi tingkat signifikan atau hubungan antara variabel. Arah korelasi ditentukan oleh nilai koefisien korelasi bernilai positif $(+)$ atau negatif $(-)$. Jika nilai koefisien positif, maka arah korelasi searah. Semakin besar nilai suatu variabel terikat, semakin besar juga nilai variabel bebasnya. Jika nilai koefisien korelasi negatif, maka arah kolerasi berlawanan arah. Semakin besar nilai suatu variabel terikat, semakin kecil nilai variabel bebasnya.

\section{HASIL DAN PEMBAHASAN}

\section{Wilayah dan Geografis}

Rumah Singgah Tabayun adalah salah satu dari empat rumah singgah yang berada di Kabupaten Bogor. Adapun tiga rumah singgah lain untuk pemberdayaan anak jalanan di Kabupaten Bogor menurut Dinas Sosial Kabupaten Bogor yakni Yayasan Umul Muhiyam, Sanggar Senja, dan Mutiara Hati. Rumah Singgah Tabayun terletak di Jalan KSR Dadi Kusmayadi, Gang PMI RT. 02 / RW. 01, Cibinong Tengah, Kecamatan Cibinong, Kabupaten Bogor. Aanak jalanan yang terdapat di Rumah Singgah Tabayun terbagi menjadi lima titik, pemilihan titik-titik lokasi penjangkauan anak jalanan tersebut berdasarkan jarak yang berdekatan dengan lokasi Rumah Singgah Tabayun. Lima titik tersebut yakni lampu merah PDAM, lampu merah Cibinong City Mall, lampu merah Daralon, bambu Kuning, dan lampu merah Cikaret.

\section{Sasaran}

Adapun sasaran peserta program yang ada di Rumah Singgah Tabayun yaitu:

1. Anak balita terlantar adalah anak yang membutuhkan perlindungan khusus (5 tahun kebawah)

2. Anak terlantar tanpa asuhan orang tua (618 tahun) meliputi anak yang mengalami perlakuan salah dan diterlantarkan oleh orang tua/keluarga atau anak kehilangan hak asuh dari orang tua/keluarga

3. Anak terpaksa bekerja dijalanan (6-18 tahun) meliputi anak yang rentan bekerja dijalan, anak yang bekerja di jalan dan anak yang hidup dijalan

\section{Visi dan Misi}

Visi rumah singgah ini adalah menjadikan anak yang mandiri dan berprestasi, sedangkan misinya sebagai berikut:

1. Menyelenggarakan perlindungan untuk anak

2. Menyelenggarakan bimbingan fisik, mental, dan sosial

3. Mengembangkan pendidikan dan pelatihan keterampilan

4. Reintegrasi anak dengan orang tua/keluarganya

\section{Tujuan Program}

Meningkatkan taraf hidup dan penghidupan warga negara, baik ideologi, politik, ekonomi, sosial budaya, serta pengetahuan dan keamanan. Di lain pihak pada kenyataannya tidak semua warga negara dapat ikut serta dan dapat menikmati hasil pembangunan tersebut, mereka adalah para Penyandang Masalah Kesejahteraan Sosial (PMKS) diantaranya anak terlantar. Salah satu akibat keterlantaran anak adalah semakin berkembangnya jumlah anak jalanan yang berkeliaran di jalan, dimana anak terpaksa dan dipaksa turun ke jalan mencari nafkah guna menunjang kelangsungan hidup diri dan keluarganya. Mereka pada umumnya adalah pedagang asongan, pengamen, kuli panggul di pasar, pembersih kendaraan, ojek payung, tukang semir sepatu, dan pemintaminta.

\section{Karakteristik Anak Jalanan}

\section{Jenis Kelamin}

Peserta Rumah Singgah Tabayun tidak dibatasi berdasarkan jenis kelamin. Tidak ada pemberlakuan syarat dan pemilihan jenis kelamin dalam peserta program sehingga dapat membuka kesempatan bagi semua anak jalanan yang berada di sekitar Rumah Singgah Tabayun untuk ikut berpartisipasi dan mengembangkan bakat yang dimilikinya. 
Tabel 1 Jumlah dan persentase anak jalanan peserta Rumah Singgah Tabayun menurut jenis kelamin, Kecamatan Cibinong, Kabupaten Bogor tahun 2016

\begin{tabular}{lcc}
\hline Jenis Kelamin & Jumlah (n) & Persentase (\%) \\
\hline Laki-laki & 23 & 76.7 \\
Perempuan & 7 & 23.3 \\
\hline Total & 30 & 100.0 \\
\hline
\end{tabular}

Usia

Usia peserta program tidak menjadi syarat, namun Rumah Singgah Tabayun lebih mengutamakan anak-anak dibawah umur 18 tahun yang masih membutuhkan peran dan bimbingan dari orang tua. Tidak hanya itu, Rumah Singgah Tabayun tidak menutup kemungkinan bagi anak jalanan yang berusia diatas 18 tahun masih bisa tetap mengikuti kegiatan yang ada.

Tabel 2 Jumlah dan persentase anak jalanan peserta Rumah Singgah Tabayun menurut tingkat usia, Kecamatan Cibinong, Kabupaten Bogor tahun 2016

\begin{tabular}{lcc}
\hline \multicolumn{1}{c}{ Usia } & Jumlah (n) & Persentase (\%) \\
\hline Anak-anak & 8 & 26.7 \\
Remaja & 10 & 33.3 \\
$\begin{array}{l}\text { Dewasa } \\
\text { muda }\end{array}$ & 12 & 40.0 \\
\hline Total & 30 & 100.0 \\
\hline
\end{tabular}

\section{Tingkat Pendidikan}

Rendahnya kemauan untuk belajar, kondisi ini disebabkan oleh keadaan lingkungan di sekitarnya (teman-teman) yang didominasi oleh anak-anak yang tidak bersekolah (putus sekolah), sehingga menyebabkan adanya perspektif dalam diri anak jalanan bahwa tidak mendapatkan pendidikan yang formal bukanlah suatu hal yang perlu dicemaskan.

Tabel 3 Jumlah dan persentase anak jalanan peserta Rumah Singgah Tabayun menurut tingkat pendidikan, Kecamatan Cibinong, Kabupaten Bogor tahun 2016

\begin{tabular}{lcc}
\hline \multicolumn{1}{c}{ Tingkat } & Jumlah & Persentase (\%) \\
Pendidikan & (n) & \\
\hline Rendah & 19 & 63.3 \\
Sedang & 8 & 26.7 \\
Tinggi & 3 & 10.0 \\
\hline Total & 30 & 100.0 \\
\hline
\end{tabular}

\section{Derajat Penghargaan Pekerjaan}

Jenis pekerjaan dibagi menjadi tiga kategori, yakni rendah, sedang, dan tinggi berdasarkan derajat penghargaan yang dimiliki dari masingmasing pekerjaan. Kategori rendah yakni pemulung dan pengemis, kategori sedang untuk pekerjaan pemain badut dan ojek payung, untuk kategori tinggi yaitu pengamen dan pemain kuda lumping.

Tabel 4 Jumlah dan persentase anak jalanan peserta Rumah Singgah Tabayun menurut derajat penghargaan pekerjaan, 2016

\begin{tabular}{lcc}
\hline $\begin{array}{c}\text { Derajat } \\
\text { Penghargaan } \\
\text { Pekerjaan }\end{array}$ & $\begin{array}{c}\text { Jumlah } \\
(\mathrm{n})\end{array}$ & $\begin{array}{c}\text { Persentase } \\
(\%)\end{array}$ \\
\hline Rendah & 3 & 20.0 \\
Sedang & 7 & 23.3 \\
Tinggi & 20 & 66.7 \\
\hline Total & 30 & 100.0 \\
\hline
\end{tabular}

\section{Jam Kerja}

Berdasarkan jam kerjanya, responden dengan kategori rendah yang bekerja kurang dari 186 jam perbulan atau kurang dari 6 jam perharinya sedangkan kategori sedang jumlah jam kerja 186-321 jam perbulan dan anak jalanan dengan kategori tinggi yang memiliki jam kerja lebih dari 321 jam perbulan atau lebih dari 11 jam perhari.

Tabel 5 Jumlah dan persentase anak jalanan peserta Rumah Singgah Tabayun menurut jam kerja perbulan, Kecamatan Cibinong, Kabupaten Bogor tahun 2016

\begin{tabular}{lrr}
\hline \multicolumn{1}{c}{ Jam Kerja } & Jumlah (n) & Persentase (\%) \\
\hline Rendah & 7 & 23.3 \\
Sedang & 13 & 43.3 \\
Tinggi & 10 & 33.3 \\
\hline Total & 30 & 100.0 \\
\hline
\end{tabular}

\section{Tingkat Pendapatan}

Tingkat pendapatan anak jalanan, dibagi menjadi tiga kategori yakni rendah, sedang, dan tinggi. 
Tabel 6 Jumlah dan persentase anak jalanan peserta Rumah Singgah Tabayun menurut tingkat pendapatan, Kecamatan Cibinong, Kabupaten Bogor tahun 2016

\begin{tabular}{lcc}
\hline $\begin{array}{c}\text { Tingkat } \\
\text { Pendapatan }\end{array}$ & $\begin{array}{c}\text { Jumlah } \\
(\mathrm{n})\end{array}$ & $\begin{array}{c}\text { Persentase } \\
(\%)\end{array}$ \\
\hline Rendah & 12 & 40.0 \\
Sedang & 12 & 40.0 \\
Tinggi & 6 & 20.0 \\
\hline Total & 30 & 100.0 \\
\hline
\end{tabular}

Pada kategori rendah, pendapatan yang dihasilkan perbulan kurang dari Rp 1.400 .000 sedangkan kategori sedang memiliki pendapatan $\mathrm{Rp} 1.400 .000$ hingga $\mathrm{Rp} 3.200 .000$ perbulan. Kategori tinggi memiliki jumlah pendapatan perbulan lebih dari Rp 3.200.000.

\section{Efektivitas Program Pemberdayaan Anak Jalanan}

Jika dipisahkan satu persatu berdasarkan empat indikator, tingkat efektivitas cenderung berada pada kategori sedang. Namun ketika sudah diakumulasikan keempat indikator tersebut maka dapat disimpulkan bahwa tingkat efektivitas Rumah Singgah Tabayun masih berada pada kategori rendah. Hal tersebut dapat terjadi karena sasaran, sosialisasi, tujuan program dan pemantauan masih banyak yang belum tercapai. Banyak anak jalanan yang kembali ke jalan setelah mengikuti program, anak-anak tidak kembali ke rumah bersama keluarganya, dan kegiatan-kegiatan yang ada tidak berkelanjutan bagi anak-anak.

Tabel 7 Jumlah dan persentase tingkat efektivitas program pemberdayaan anak jalanan di Rumah Singgah Tabayun, Kecamatan Cibinong, Kabupaten Bogor tahun 2016

\begin{tabular}{lrr}
\hline \multicolumn{1}{c}{$\begin{array}{c}\text { Tingkat } \\
\text { Efektivitas }\end{array}$} & Jumlah (n) & Persentase (\%) \\
\hline Rendah & 14 & 46.7 \\
Sedang & 10 & 33.3 \\
Tinggi & 6 & 20.0 \\
\hline Total & 30 & 100.0 \\
\hline
\end{tabular}

\section{Latar Belakang menjadi Anak Jalanan}

Kehidupan di jalanan memang sangat ekstrim ketika seseorang melihat sekilas secara kasat mata. Di samping itu, mereka memiliki alasan atau latar belakang sendiri dalam memutuskan menjadi anak jalanan. Adapun latar belakang responden menjadi anak jalanan sangat beragam, namun secara garis besar dapat dibagi menjadi empat yakni:

\section{Memenuhi kebutuhan ekonomi}

Keberadaan anak jalanan pada penelitian ini secara garis besar disebabkan karena kesulitan ekonomi. Kesulitan ekonomi rumah tangga menyebabkan anak ikut membantu dalam pencarian nafkah keluarga. Keluarganya yang miskin membuat seorang anak harus bertanggung jawab untuk membantu meringankan beban keluarga.

\section{Hilangnya fungsi keluarga}

Seorang anak membutuhkan peran keluarga ketika ia tumbuh dan berkembang, namun saat peran keluarga tersebut tidak berfungsi maka seorang anak dapat melakukan pemberontakan kepada diri dan lingkungannya. Tidak sedikit kasus responden yang turun ke jalanan karena orang tua mereka yang bercerai, menikah lagi dan tidak peduli dengan anaknya. Adapula anak yang terlalu sering dimarahi oleh ayahnya hingga dia diusir dan benar-benar memutuskan untuk meninggalkan rumah.

\section{Tambahan uang saku}

Bagi anak yang turun jalanan dengan alasan tambahan uang saku biasanya mereka hanya ikut-ikutan teman dan merasa nyaman karena bisa mengenal teman lebih banyak lagi. Selain itu, anak merasakan mendapatkan uang lebih dengan mudah sehingga ia mulai terbiasa dengan hal tersebut.

\section{Rekreasi}

Terlepas dari pemenuhan kebutuhan ekonomi, terdapat anak-anak turun ke jalan berdasarkan kepuasan pribadi atau hanya sekedar rekreasi. Pada dasarnya, mereka mampu secara finansial namun merasa bahwa jalanan merupakan sesuatu yang spesial untuk mencari dan menunjukkan makna kebebasan. Bisa jadi karena ajakan teman maupun keingin pribadi responden untuk menyalurkan bakat yang mereka miliki.

Meskipun keluarganya sudah mapan atau cukup, beberapa anak juga menyukai kehidupan jalanan karena memiliki tingkat kenyamanan 
yang tinggi dan memberi kepuasan terhadap beberapa anak yang sudah terbiasa hidup di jalan.

\section{Hubungan Karakteristik Anak Jalanan Dengan Tingkat Efektivitas Program Pemberdayaan Anak Jalanan}

Hubungan antara karakteristik peserta program dengan tingkat efektivitas dapat dilihat dari tabel 8. Karakteristik responden yang berhubungan dengan tingkat efektivitas adalah usia, derajat penghargaan pekerjaan, dan jam kerja. Ketiga variabel tersebut memiliki koefisien dari hasil uji rank spearman yang berarti memiliki hubungan dengan arah negatif.
Tabel 8 Koefisien hubungan karakteristik anak jalanan dengan tingkat efektivitas program pemberdayaan anak jalanan di Rumah Singgah Tabayun, Kecamatan Cibinong, Kabupaten Bogor tahun 2016

\begin{tabular}{lr}
\hline \multicolumn{1}{c}{ Karakteristik } & \multicolumn{1}{c}{ Tingkat Efektivitas } \\
\hline Jenis Kelamin & 0.0600 \\
Usia & $-0.421^{*}$ \\
Tingkat Pendidikan & -0.0730 \\
Derajat Penghargaan & $-0.453^{*}$ \\
Pekerjaan & \\
Jam Kerja & $-0.409^{*}$ \\
Tingkat Pendapatan & -0.0060 \\
\hline
\end{tabular}

\section{Hubungan Usia dengan Tingkat Efektivitas Program}

Berdasarkan hasil pengamatan (Tabel 9), semakin dewasa anak jalanan maka semakin kurang peduli dengan kegiatan-kegiatan yang ada di Rumah Singgah Tabayun.

Tabel 9 Jumlah dan persentase responden menurut tingkat efektivitas program dengan usia anak jalanan di Rumah Singgah Tabayun, Kecamatan Cibinong, Kabupaten Bogor tahun 2016

\begin{tabular}{llcccc}
\hline & \multirow{2}{*}{ Usia } & \multicolumn{3}{c}{ Tingkat Efektivitas } & \multirow{2}{*}{ Total } \\
\cline { 3 - 5 } Anak-anak & Jumlah (n) & Rendah & Sedang & Tinggi & 8 \\
& Persentase (\%) & 1 & 3 & 4 & 8 \\
\multirow{2}{*}{ Remaja } & Jumlah (n) & 5.5 & 37.5 & 50.0 & 100.0 \\
\multirow{2}{*}{ Dewasa muda } & Persentase (\%) & 50.0 & 5 & 0 & 10 \\
\multirow{2}{*}{ Total } & Jumlah (n) & 8 & 50.0 & 0.0 & 100.0 \\
& Persentase (\%) & 66.7 & 2 & 2 & 12 \\
& Jumlah (n) & 14 & 16.7 & 16.7 & 100.0 \\
\hline
\end{tabular}

Mereka merasa bahwa mengikuti program Tabayun menghabiskan banyak waktu yang seharusnya dapat digunakan untuk mencari uang. Berbeda dengan anak-anak dengan usia yang cenderung lebih muda, rasa ingin tahu mereka masih sangat tinggi dan tertarik untuk mengikuti kegiatan-kegiatan baru yang terdapat di Rumah Singgah Tabayun. Hanya saja, untuk anak-anak usia dini terkadang terhalang oleh orang tua yang tidak mengizinkan mengikuti kegiatan karena dapat mengurangi waktu anak bekerja.

\section{Hubungan Derajat Penghargaan Pekerjaan dengan Tingkat Efektivitas Program}

Pada Tabel 10 menyatakan bahwa semakin tinggi derajat penghargaan pekerjaan anak jalanan maka semakin rendah tingkat efektivitas program tersebut. Hal tersebut dapat terjadi karena anak jalanan dengan kategori derajat penghargaan pekerjaan yang tinggi akan semakin nyaman untuk berada di jalanan dari pada anak-anak dengan kategori rendah. Mereka akan lebih sulit dalam meninggalkan pekerjaan dan lingkungan mereka sehari-hari sehingga dapat membuat program tersebut menjadi tidak efektif dilakukan pada anak jalanan dengan derajat penghargaan pekerjaan yang tinggi berdasarkan persepsi mereka. 


\section{Hubungan Jam Kerja dengan Tingkat Efektivitas Program}

Merujuk pada Tabel 11 dapat kita lihat bahwa jam kerja anak jalanan memiliki hubungan negatif dengan tingkat efektivitas program. Dimana, semakin tinggi jam kerja anak jalanan maka semakin rendah tingkat efektivitas program tersebut.

Jam kerja pada kategori rendah yakni anak jalanan yang bekerja kurang dari 186 jam

Tabel 10 Jumlah dan persentase responden menurut tingkat efektivitas program dengan jenis pekerjaan responden anak jalanan di Rumah Singgah Tabayun, 2016

\begin{tabular}{|c|c|c|c|c|c|}
\hline \multirow{2}{*}{\multicolumn{2}{|c|}{ Derajat Penghargaan Pekerjaan }} & \multicolumn{3}{|c|}{ Tingkat Efektivitas } & \multirow{3}{*}{$\frac{\text { Total }}{3}$} \\
\hline & & \multirow{2}{*}{$\begin{array}{c}\text { Rendah } \\
1\end{array}$} & \multirow{2}{*}{$\frac{\text { Sedang }}{0}$} & \multirow{2}{*}{$\frac{\text { Tinggi }}{2}$} & \\
\hline Ponduh & Jumlah (n) & & & & \\
\hline кеndan & Persentase (\%) & 33.3 & 0 & 66.7 & 100.0 \\
\hline \multirow{2}{*}{ Sedang } & Jumlah (n) & 0 & 6 & 1 & 7 \\
\hline & Persentase $(\%)$ & 0 & 85.7 & 14.3 & 100.0 \\
\hline \multirow{2}{*}{ Tinggi } & Jumlah (n) & 13 & 4 & 3 & 20 \\
\hline & Persentase $(\%)$ & 65.0 & 20.0 & 15.0 & 100.0 \\
\hline \multirow{2}{*}{ Total } & Jumlah (n) & 14 & 10 & 6 & 30 \\
\hline & Persentase (\%) & 46.7 & 33.3 & 20.0 & 100.0 \\
\hline
\end{tabular}

Tabel 11 Jumlah dan persentase responden menurut tingkat efektivitas dengan jam kerja responden anak jalanan di Rumah Singgah Tabayun, 2016

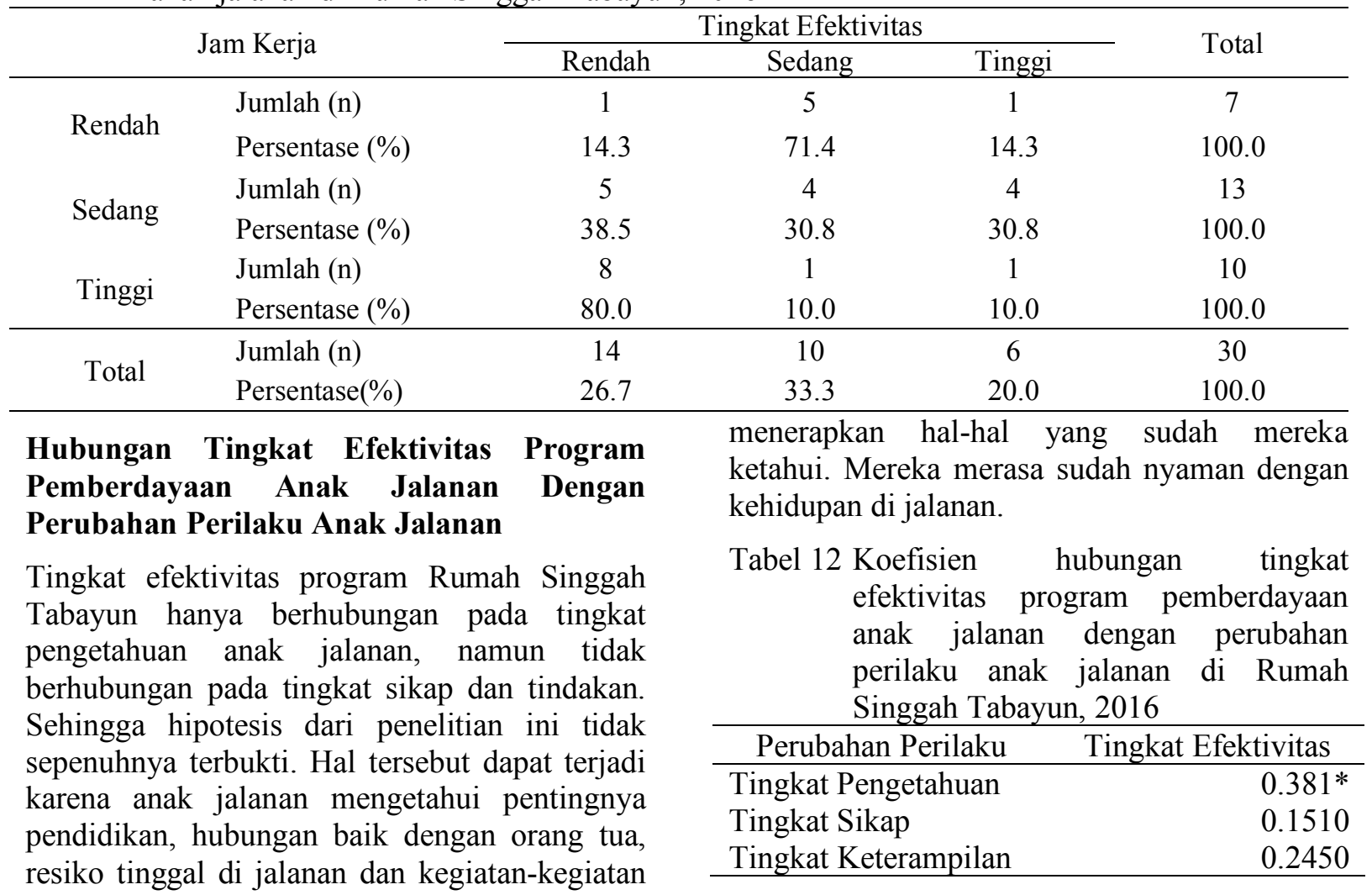




\section{Hubungan Tingkat Efektivitas Program dengan Tingkat Pengetahuan}

Merujuk pada Tabel 13, terdapat hubungan antara tingkat efektivitas program dengan tingkat pengetahuan anak jalanan. Dimana, kegiatan-kegiatan yang terdapat di Rumah
Singgah Tabayun dapat merubah pengetahuan anak jalanan mengenai pentingnya pendidikan, hubungan baik dengan keluarga, dan baikburuknya kegiatan di jalanan.

Tabel 13 Jumlah dan persentase responden menurut tingkat efektivitas program dengan tingkat pengetahuan responden anak jalanan di Rumah Singgah Tabayun, 2016

\begin{tabular}{clcccc}
\hline \multirow{2}{*}{ Tingkat Pengetahuan } & \multicolumn{3}{c}{ Tingkat Efektivitas } & \multirow{2}{*}{ Total } \\
\cline { 2 - 5 } \multirow{2}{*}{ Rendah } & Jumlah (n) & Rendah & Sedang & Tinggi & \\
& Persentase (\%) & 1 & 0 & 0 & 1 \\
& Jumlah (n) & 100.0 & 0 & 0 & 100.0 \\
\multirow{3}{*}{ Tinggiang } & 8 & 4 & 1 & 13 \\
& Persentase (\%) & 61.5 & 30.8 & 7.7 & 100.0 \\
& Jumlah (n) & 5 & 6 & 5 & 16 \\
& Persentase (\%) & 31.3 & 37.5 & 31.3 & 100.0 \\
\hline \multirow{2}{*}{ Total } & Jumlah (n) & 14 & 10 & 6 & 30 \\
& Persentase (\%) & 46.7 & 33.3 & 20.0 & 100.0 \\
\hline
\end{tabular}

Perubahan yang diharapkan adalah dari tidak mengetahui menjadi mengetahui, dari tidak paham menjadi paham, dari tidak mengerti menjadi mengerti tentang sesuatu yang dipelajari individu yang belajar.

\section{SIMPULAN DAN SARAN}

\section{Simpulan}

1. Tingkat pendidikan formal anak jalanan masih sangat rendah, sebagian besar tidak pernah sekolah dan tidak tamat Sekolah Dasar. Derajat penghargaan pekerjaan berada pada kategori tinggi yaitu sebagai pengamen dan pemain kudang lumping. Jam kerja anak jalanan berada pada kategori sedang yakni 6 hingga 10 jam perhari. Selain itu, tingkat pendapatan anak jalanan juga berada pada kategori sedang yakni sebesar Rp1.400.000 hingga Rp 3.200.000 perbulan.

2. Berdasarkan analisis empat indikator tingkat efektivitas program pemberdayaan anak jalanan yang meliputi ketepatan sasaran, keberhasilan sosialisasi, pencapaian tujuan, dan pemantauan program menunjukkan bahwa program pemberdayaan anak jalanan di Rumah Singgah Tabayun memiliki tingkat efektivitas yang rendah.

3. Variabel hubungan karakteristik anak jalanan dengan tingkat efektivitas program pemberdayaan anak jalanan tidak semuanya memiliki hubungan yang signifikan. Adapun variabel karakteristik anak jalanan yang memiliki hubungan signifikan dengan tingkat efektivitas program yaitu usia, jenis pekerjaan, dan jam kerja anak jalanan.

4. Variabel hubungan tingkat efektivitas program pemberdayaan anak jalanan dengan perubahan perilaku anak jalanan tidak semuanya memiliki hubungan yang signifikan. Tingkat efektivitas program pemberdayaan anak jalanan di Rumah Singgah Tabayun hanya memiliki hubungan signifikan dengan tingkat pengetahuan anak jalanan.

\section{Saran}

1. Untuk pengembangan keilmuan bagi civitas akademika, penelitian ini perlu adanya pembanding antar dua lokasi yang beragam sebagai pembanding antara tingkat efektivitas di daerah mana yang paling berhasil dan berkelanjutan apabila Rumah 
Singgah Tabayun diadakan di dua lokasi yang berbeda sehingga mampu memberikan dan menambah informasi yang bermanfaat bagi khalayak.

2. Untuk pengembangan keilmuan bagi civitas akademika, perlu dilakukan penelitian mengenai efektivitas program yang ditinjau dari sisi pengelola program sehingga mengetahui kendala-kendala yang terjadi dalam sudut pandang yang berbeda guna memperdalam penelitian ini.

3. Untuk pemerintah disarankan agar memberdayakan ekonomi orang tua anak jalanan karena akar permasalahannya berada pada kondisi keluarga yang miskin. Ketika orang tua sudah mampu memenuhi kebutuhan ekonomi keluarga secara mandiri, maka mereka tidak akan lagi melibatkan anak untuk turun ke jalan dalam membantu perekonomian keluarga.

4. Untuk pemerintah dan petugas kepolisian agar memberantas oknum-oknum tidak bertanggung jawab yang merugikan anak jalanan dalam hal pemungutan liar ketika sedang melakukan razia.

5. Untuk pemerintah ataupun lembaga sosial masyarakat diharapkan mampu menyalurkan dan memberikan pekerjaan yang layak kepada anak jalanan yang memiliki keterbatasan penampilan dalam hal ini bertato, karena perusahaan-perusahaan yang ada tidak mau menerima karyawan dengan kondisi tersebut. Penulis merekomendasikan untuk lembaga "Sekolah Relawan" maupun lembaga sejenis agar merekrut pengurusnya dari kalangan anak jalanan.

6. Bagi anak jalanan agar mengikuti kegiatan di Rumah Singgah Tabayun minimal mengikuti kegiatan "Kejar Paket" karena ijazah pendidikan sangat diperlukan untuk masa depan.

\section{DAFTAR PUSTAKA}

Amelia R. 2015. Efektivitas Pelaksanaan Program Penanganan Anak Jalanan di Dinas Sosial Kota Makassar. Skripsi [Internet]. [Diunduh pada 28 Maret 2016]. Tersedia pada: http://repository.unhas.ac.id/bitstrea $\mathrm{m} /$ handle/123456789/14610/SKRIPSI \%20RIZCAH\%20AMELIA.pdf?sequ ence $=1$

Ariwibowo I. 2009. Upaya pemberdayaan anak jalanan melalui rumah singgah diponegoro Yogyakarta. Jurnal Dimensia [Internet]. [Diunduh pada 14 Septembr 2016]. 03(01):35-53. Tersedia pada: http://journal.uny.ac.id/index.php/dim ensia/article/view/3408

Asmorowati S. 2008. Efektivitas kebijakan perlindungan pekerja anak (child labour) dengan Fokus Anak Jalanan di Surabaya. Jurnal [Internet]. [Diunduh pada 29 Maret 2016]. 07 (01): 31-44. Tersedia pada: http://journal.unair.ac.id/downloadfullpapers-04\%20A4\%20\%20April \%202008\%20_3144_.pdf

Badan Kesejahteraan Sosial Nasional. 2000. Anak Jalanan di Indonesia: Permasalahan dan Penanganannya. Jakarta.

Badan Pusat Statistik [BPS]. 2008. Fenomena Anak Jalanan di DKI Jakarta Triwulan I. Tersedia pada: www.BPS.go.id

Budiani NW. 2007. Efektivitas program penanggulangan pengangguran karang taruna eka taruna bhakti desa Sumerta Kelod kecamatan Denpasar Timur kota Denpasar. Jurnal Ekonomi dan Sosial [Internet]. 02(01): 49-57. Tersedia pada: http://ojs.unud.ac.id/index.php/input/a rticle/viewFile/3191/2288

Departemen Sosial Republik Indonesia. 2001. Petunjuk Teknis Pelayanan Sosial Anak Jalanan, Jakarta: Departemen Sosial Republik Indonesia.

Effendy OU. 2003. Ilmu Komunikasi Teori dan Praktek. Bandung(ID): PT Remaja Rosdakarya.

Fadilah MM, Suyanto T. 2013. Peranan sanggar alang-alang Surabaya dalam upaya pemberdayaan anak jalanan. Jurnal Kajian Moral dan Kewarganegaraan [Internet]. [Diunduh pada 26 Maret 2016]. 01(01): $101-115$. Tersedia pada

http://ejournal.unesa.ac.id/index.php/j 
urnal-pendidikan-

kewarganegaraa/article/view/1467

Gibson dkk. 1984. Organisasi dan Manajemen Perilaku Struktur Proses. Djoerban Wahid, penerjemah. Jakarta(ID): Penerbit Erlangga.

Hungu. 2007. Demografi Kesehatan Indonesia. Jakarta(ID): Penerbit Grasindo.

Kementrian Sosial Republik Indonesia. 2016. Jumlah anak jalanan di Indonesia. Tersedia

pada:http://www.kemsos.go.id/modul es.ph

$\mathrm{p}$ ? name $=$ News $\&$ file $=$ article $\&$ sid $=189$ 59

Kespa KY. 2006. Analisis Peranan Rumah Singgah dalam Upaya Perlindungan Anak Jalanan (Kasus Rumah Singgah Rumah Kita, Kelurahan Gunung Batu, Kecamatan Bogor Barat, Kabupaten Bogor, Provinsi Jawa Barat) [Skripsi]. Bogor(ID): Institut Pertanian Bogor.

Kumalasari PPW. 2013. Konsep diri anak jalanan usia remaja di wilayah Semarang Tengah. Jurnal Keperawatan Jiwa [Internet]. [Diunduh pada 26 Maret 2016]. 01(02): $\quad$ 156-160. http://jurnal.unimus.ac.id/index .php/JKJ/article/view/977

Kushartati S. 2004. Pemberdayaan anak jalanan. Humanitas: Indonesian Psychological Journal [Internet]. [Diunduh pada 27 Maret 2016]. 01 (02) : 45-54. Tersedia pada: $\mathrm{http} / / /$ journaldatabase.info/articles/ pemberdayaan_anak_jalanan.html

Mugniesyah SS. 2006. Bahan Ajar Penyuluhan Pertanian Bagian 1. Bogor(ID): Fakultas Ekologi Manusia.

Narti S. 2015. Hubungan karakteristik petani dengan efektivitas komunikasi penyuluhan pertanian dalam program SL-PTT. Jurnal [Internet]. [Diunduh pada 23 Januari 2017]. 02(02): 40-52. Tersedia pada: http://jurnal.unived.ac.id/index.php/pr of/article/view/173/163

Nasdian FT. 2003. Modul Pengembangan Masyarakat. Bogor(ID): IPB Press.

Purwanti EP. 2010. Pemberdayaan Anak Jalanan melalui Program Coorporate Social Responsibility (CSR) Rumah
Singgah. Skripsi [Internet]. [Diunduh pada 29 Maret 2016]. Tersedia pada: http://repository.ipb.

ac.id/bitstream/handle/123456789

/60055/

I10epp.pdf? sequence $=1 \&$ isAllowed $=$ $\mathrm{y}$

Robbins SP. 1994. Organization Theory : Structure, Design, and Applications. New York(US): Pretice Hall Englewood

Roux JL, Smith CS. 1998. Public perceptions of and reactions to street children. Adolescence Journal [Internet]. [Diunduh pada 20 Desember 2016]. 33(132). Tersedia pada: http://download.portalgaruda.org/artic le.php? article $=124087 \& \mathrm{val}=5536$

Sari RFS. 2015. Studi deskriptif tentang efektivitas pemberdayaan dalam meningkatan kemandirian anak jalanan di unit pelaksana teknis dinas (UPTD) kampung anak negeri dinas sosial kota Surabaya. Jurnal Kebijakan dan Manajemen Publik [Internet]. [Diunduh pada 27 Maret 2016]. 03 (01) : 1-9. Tersedia pada: http://journal.unair.ac.id/downloadfullpapers-kmp500fbc7e9dfull.pdf

Satries WI. 2011. Efektivitas program pemberdayaan pemuda pada organisasi kepemudaan Al Fatih Ibadurrohman Kota Bekasi [tesis]. Jakarta(ID): Universitas Indonesia

Singarimbun I. 2006. Metode Penelitian Survei. Jakarta(ID): Pustaka LP3ES.

Siregar H, Rani Z, Suriadi A. 2006. Faktor dominan anak menjadi anak jalanan di kota Medan. Jurnal Studi Pembangunan [Internet]. [Diunduh pada 27 Maret 2016]. 01 (02) : 22-31. Tersedia pada: http://repository.usu. ac.id/bitstream/123456789/15379/1/st p-apr2006-\%20\%283\%29.pdf

Suhartini T, Panjaitan NK. 2009. Strategi bertahan hidup anak jalanan: kasus anak jalanan di kota Bogor, provinsi Jawa Barat. Sodality: Jurnal Transdisiplin Sosiologi, Komunikasi dan Ekologi Manusia [Internet]. [Diunduh pada: 28 Maret 2016]. 03 (02) : 215-230. Tersedia pada: 
http://journal.ipb.ac.id/index.php/soda lity/article/viewFile/5865/4530

Suharto E. 2005. Membangun Masyarakat Memberdayakan Rakyat. Jakarta(ID): PT. Refika Aditama.

Suyanto B. 2005. Pemberdayaan Komunitas Marginal di Perkotaan. Yogyakarta(ID): PT. LkiS Pelangi Aksara.

Sya'bana F. 2013. Efektivitas pelaksanaan program kesejahteraan sosial anak jalanan oleh yakmi kelurahan Aur kecamatan Medan Maimun. Jurnal [Internet]. [Diunduh pada 30 Maret 2016]. 02(04): 1-11. Tersedia pada: http://jurnal.usu.ac.id/index.php/ws/ article/view/6223

Undang-Undang Republik Indonesia Nomor 23 Tahun 2002 tentang Perlindungan Anak, 2003. Kementrian Pemberdayaan Perempuan RI dan Departemen Sosial RI.

Undang-Undang Republik Indonesia Nomor 35 tahun 2014 tentang Perubahan atas Undang-Undang Nomor 23 Tahun 2002 tentang Perlindungan Anak. Tersedia pada: http://www.kpai.go.id/files/2013/09/u u-nomor-35-tahun-2014-tentangperubahan-uu-pa.pdf

Undang-Undang Ketenagakerjaan No 13 Tahun 2003. Tersedia pada: http.//www.dprin.

go.id/regulasi/2003/03/UU_13_03.pdf

Unicef. 2003. Pengertian Konvensi $\bar{H}^{-} \bar{k}$ Anak. Bandung(ID): PT. Enka Parahiyangan 